\title{
Communication Skills of Classroom Teachers According to Various Variables
}

\author{
Selma Güleç ${ }^{1, *}$, Burcu Şentürk Leylek ${ }^{2}$ \\ ${ }^{1}$ Education Faculty, Uludağ University, Turkey \\ ${ }^{2}$ Educational Faculty, Educational Sciences Institute, Uludağ University, Turkey
}

Copyright $\odot 2018$ by authors, all rights reserved. Authors agree that this article remains permanently open access under the terms of the Creative Commons Attribution License 4.0 International License

\begin{abstract}
In this study, it was investigated into if communication skills of classroom teachers working in the first stage of elementary education significantly differed according to such variables as gender, service length, school of graduation. The data were obtained via using the scale for "Teachers' Communication Skills" developed by Canan Çetinkanat. Moreover, a "Personal Information Form" including questions about gender, service length and school of graduation was prepared and administered by the researchers. The sample of the study included a total of 77 elementary school teachers selected via an appropriate sampling method from among those who were working in the first stage of 5 different elementary schools in the provincial center of Bursa. The Cronbach's Alpha reliability coefficient obtained as a result of the administration was $r=0,80$. As a result of the study, it was found that the classroom teachers' communication skills did not differ significantly according to the variables of gender and service length, but they differed according to the variable of school of graduation.
\end{abstract}

Keywords Elementary Education, Classroom Teacher, Communication Skills

\section{Introduction}

Humans are in continuous interaction and communication with their environments. In order for necessary information to be produced and transferred between humans, communication is needed [1]. In today's societies, one of the most fundamental problems which individuals have is interpersonal relations. Problems confronted in interpersonal relations affect individuals rather deeply and take place in life as one of the most basic problems of today. Many people with whom individuals interact with starting from the time when they are born, mainly the closest ones, play an active role in determining their personality, psychological health, attitudes and behavior patterns [2]. In our day called Information Age and in which talents are attached more importance, individuals need to establish communication with other individuals in the society in order to meet their needs, share their feelings and thoughts, acquire information and be able to live healthily in their life spaces [3]. According to Dökmen [4], communication is the basic condition for a person to be able to adapt to environment, social reality, and other people. For in an environment where there is no communication, there is no information society caused by information production, dissemination and interaction between people, either. More specifically, proper and realistic communication is considered as one of the basic conditions of interpersonal adaptation, solidarity and cooperation, social cohesion, people's understanding each other and developing empathy [5]. For the basic condition of creating a healthy, cohesive social structure is a quality social life composed of a relationship network based on more defenseless, realistic, open and honest human relations and humans trusting and communicating with one another openly [6].

When it is discussed with a general evaluation, communication is defined as the flow of feelings and ideas between individuals. As for communication in the classroom environment, it takes place as a result of educators' sharing behaviors related to a subject with students with the aim of creating these behaviors in them $[6,7,8]$

\section{Importance of Communication in Terms of Teaching Profession}

The important point in the question how teachers will train students and how they will be trained in 2000's is that all teachers, regardless of their fields, should be aware that they need to establish communication with students. The style of this communication will determine greatly students' communication styles, too. In the learning 
environment, they may turn into alienated individuals educated without being valued, not taking pleasure from but hating learning, having increasing health problems, undertaking and creating problems at individual and social levels or, conversely, they may become individuals who find themselves and others valuable, are sensitive to people and social problems, productive and able to establish effective communication as well [9]. In the classroom, teachers should be able to transfer their knowledge and thoughts, have effective expression skills to ask students questions and have effective listening skills to understand students' questions, thoughts and opinions [10].

It should be kept in mind that the school is one of the environments where the communication process takes place most intensively; in addition to being a place where knowledge is acquired, it is also a very important environment for the acquisition of interpersonal communication skills. [11] In accordance with this fact, Çetinkanat [12] examined teachers' communication skills in the classroom under five dimensions. These dimensions are:

a) Empathy: Empathy takes the first place among a teacher's communication skills. Empathy means understanding others and helping others understand themselves. According to Rogers, empathic understanding covers the ability to understand how others perceive life).

b) Transparency: Transparency includes an individual's wearing his/her heart on his/her sleeve, and at the same time, explaining his/her feelings and thoughts sincerely without trying to hide. In his/her relations with students, a teacher, who is able to be transparent, is expected to be open and clear not only in his/her feelings but also in his/her lessons, teaching style and exams.

c) Equality: Relationship between a teacher and a student should be equal because of being individuals and at a level to create a positive learning atmosphere without putting any psychological distance arising from role and status difference between them. Disciplining without being authoritarian requires knowledge and skill.

d) Effectiveness: This dimension covering a teacher's performing teaching and checking if learning has been achieved includes a series of teacher behaviors. The teacher should aim to achieve positive mental and behavioral changes in students, which is possible to combine these in developmental sense.

e) Competence: A teacher's having been trained well in his/her field, his/her competence in transferring his/her knowledge is another important dimension among a teacher's communication skills. Besides having been well-trained, it is also important that a teacher should be able to establish communication with his/her students when presenting knowledge.

Effective communication skills are important in terms of professional and personal characteristics of teaching. For, in most general sense, the learning process is a communication process. In this process, sending-receiving meaningful message is closely related to a teacher's competencies. The quality of in-class communication is an important element affecting students' personality developments and success levels [13].

Undoubtedly, one of the most important issues in the profession of teaching is that, regardless of their fields, all teachers should be aware that they need to establish communication with their students. This communication style will determine students' communication styles. Today the teacher type considering him/herself responsible only for teaching is rapidly becoming out-of-date. A contemporary, effective teacher does not only teach but he/she also attaches importance to humans, can establish effective communication with him/herself and his/her environment, has power to solve problems which he/she encounters, shoulders the responsibility of training individuals with developed self-confidence. If the teacher and the student as a source and a target use feedback effectively by changing their roles continuously in the communication process, they can achieve effective communication. For this reason, a teacher's realizing communication process bi-directionally and by achieving students' effective participation is important for achieving learning [14].

Attitudes and behaviors which teachers exhibit toward their students will not only differentiate students' attitudes, behaviors toward and interests in their teachers but also communication skills which teachers use in their communication with their students have an important place [15]. It is observed that teachers perceiving themselves as efficient and effective teachers have higher communication skills [16].

According to Jones, V. F. \& Jones [17], use of communication skills help teachers behave toward students sincerely, feel happy in their relations with students, have students express openly what they need and desire, understand their students better, adopt them, create positive thoughts about them and create environments in which students can express themselves and develop responsibility feelings and give more positive responses toward their teachers and peers.

For this reason, teachers should take some important points into consideration in order to develop the teacher-student communication: creating a warm classroom atmosphere, treating all students equally, using a positive language and rewarding desired behaviors. These activities contributing to communication increase the appearance frequency of desired behaviors and decreases undesired behaviors within the course of time. [18] For this reason, in classroom management, having good communication skills will enable classroom teachers to settle conflicts and overcome problems. Because of this, in the creation of a positive classroom atmosphere and the rewarding of positive behaviors, quality communication is of vital importance for classroom teachers. [19] 
In order to establish open and effective communication with students, teachers need to have three skills, namely non-authoritarian character, emphatic responsibility and problem solving. For this reason, they need to describe the problem clearly, use an open body language and explain the appropriate behavior in relation to the solution of the problem. The emphatic responsibility skill covers showing students that $\mathrm{s} / \mathrm{he}$ can see events from their points of view. The problem solving skill covers eliminating the dispute. In relation to the elimination of the dispute, the teacher should describe the problem, discuss different solutions and put one of the solutions into practice. [20]

\section{Problem Statement}

Is there a significant relationship between the communication skills of the elementary first stage classroom teachers and their genders, service lengths and graduation schools?

The problems for which answers were sought in the study are these:

Do the communication skills of the elementary first stage classroom teachers show any significant differences according to gender?

Do the communication skills of the elementary first stage classroom teachers show any significant differences according to service length?

Do the communication skills of the elementary first stage classroom teachers show any significant differences according to type of graduation school?

\section{Materials and Methods}

The study is in the screening model. The screening model is an approach aiming to describe a past or present situation as it was/is. In the study, the "Teacher Communication Skills Scale" developed by Çetinkanat [12] was used.

\section{Population and Sample}

The population of the study was composed of classroom teachers working in the elementary schools in the province of Bursa. Since it was impossible to reach the whole of the population, the convenience sampling method was used in the study. The sample of the study was composed of 77 classroom teachers from 5 elementary schools in the city center of Bursa. When the teachers included in the sample were distributed according to gender, it was observed that $57 \%$ of them were female (44) and $43 \%$ were male (33).

\section{Data Collection Tool}

In the scale developed by Çetinkanat (1997) in order to evaluate teachers' perceptions about their own communication skills, there are 44 items and the items are scored via using a 6-point Likert type scale as 6 "always", 5 "almost always", 4 "most of the time", 3 "sometimes", 2 "rarely", 1 "never". In the scale, the items numbered 2, 23 and 40 are scored reversely. In the original study, the Cronbach's alpha value calculated for the internal consistency of the scale was 0,81 . In this study, the Alpha Reliability Coefficient was found as 0.80 .

\section{Data Analysis}

In the analysis of the data, the "SPSS (Statistical Packages for Social Sciences)" For Windows package program was used. The answers given to the questions in the measurement tool were coded in the computer in accordance with the sub-problems.

In the analysis of the data obtained as a result of the administration of the scale, the "descriptive statistics" techniques (frequency, percentage, arithmetic mean) were used. In order to determine if the dependent variable showed normal distribution, the single-sample Kolmogorov Smirnov test was employed. According to the obtained results, it was observed that the dependent variable showed normal distribution (z: $0,723 \mathrm{p}>0,672$ ). For this reason, of parametric tests, the t- test and the ANOVA test were used. The answer choices in the discontinuous scale were made "continuous" via a scale developed with the aim of interpreting the results obtained with statistical procedures. 5 intervals in the section of frequency of encountering problems were divided into 6 choices (5: $6=0.83)$; the found number choices were interpreted by adding via starting from the representative lowest number as: $1.00-1.82$ Never, $1.83-2.66$ Rarely, $2.67-3.50$ Sometimes, $3.51-4.34$ Most of the time, $4.35-$ 5.18 Almost always and 5.19-6.00 Always. When writing the results, the significance level of 0.05 was taken as the criterion.

\section{Findings}

Having examined the teachers' communication skills according to gender, service length and graduation school type, the following findings were reached.

The results of the independent samples t-test employed for the in order to determine if the classroom teachers' communication skills changed according to their gender from the answers which they gave to the "Communication Skills Scale" are given in Table 1.

Table 1. The Independent Samples T-Test Results Indicating How the Teachers' Communication Skills Changed According to Gender

\begin{tabular}{|c|c|c|c|c|c|}
\hline Gender & $\mathrm{N}$ & $\bar{X}$ & $\mathrm{~S}$ & $\mathrm{t}$ & $\mathrm{p}$ \\
\hline Female & 44 & 220,52 & 18,04 &, 60 &, 86 \\
\hline Male & 33 & 217,94 & 18,99 & & \\
\hline $\mathrm{p}>0,05$
\end{tabular}

When Table 1 is examined, it is observed that the classroom teachers' communication skills do not change significantly according to the variable of gender $(\mathrm{p}>0,05)$. 
Table 2. The Classroom Teachers' Communication Skills According to Their Service Lengths (One Way ANOVA)

\begin{tabular}{|c|c|c|c|c|c|}
\hline $\begin{array}{c}\text { Service } \\
\text { Length }\end{array}$ & $\mathrm{N}$ & $\bar{X}$ & Ss & $\mathrm{F}$ & $\mathrm{P}$ \\
\hline $1-5$ & 21 & 221,3333 & 9,89107 & & \\
\hline $6-10$ & 27 & 214,0000 & 22,79845 & & \\
\hline $11-15$ & 7 & 221,1429 & 17,04336 & 1,517 &, 207 \\
\hline $16-20$ & 3 & 230,3333 & 18,03700 & & \\
\hline $21-25$ & 8 & 229,8750 & 14,19696 & & \\
\hline $26+$ & 11 & 217,3636 & 20,51474 & & \\
\hline Total & 77 & 219,4156 & 18,37214 & & \\
\hline $\mathrm{*}>0,05$ & &
\end{tabular}

When Table 2 is examined, it is observed that the classroom teachers' communication skills do not change significantly according to their service lengths $(p>0,05)$

Table 3. The Classroom Teachers' Communication Skills According to Their Graduation School (One Way ANOVA)

\begin{tabular}{|c|c|c|c|c|c|}
\hline Graduation & $\mathrm{N}$ & $\bar{X}$ & $\mathrm{Ss}$ & $\mathrm{F}$ & $\mathrm{P}$ \\
\hline $\begin{array}{c}\text { Education } \\
\text { Institute }\end{array}$ & 6 & 226,0000 & 10,97269 & & \\
\hline $\begin{array}{c}\text { Undergraduate } \\
\text { Degree - } \\
\text { Education } \\
\text { Faculty }\end{array}$ & 47 & 215,7234 & 19,53781 & & \\
\hline $\begin{array}{c}\text { Undergraduate } \\
\text { Degree- Others }\end{array}$ & 13 & 230,4615 & 12,84922 & 2,966 &, 038 \\
\hline $\begin{array}{c}2+2 \\
\text { Undergraduate } \\
\text { Degree } \\
\text { Completion }\end{array}$ & 7 & 213,4286 & 16,60178 & & \\
\hline Postgraduate & 4 & 227,5000 & 16,90168 & & \\
\hline Total & 77 & 219,4156 & 18,37214 & & \\
\hline$* 0,05>\mathrm{p}$ & & &
\end{tabular}

When Table 3 is examined, it is observed that the classroom teachers' communication skills changed significantly according to their graduation school $(0,05>\mathrm{p})$. According to this, it can be stated that the Education Faculty graduate classroom teachers had higher communication scores compared to those having graduated from other faculties. Similarly, it was determined that the communication scores of the teachers having graduated by completing $2+2$ undergraduate degree differed significantly compared to those having graduated from other faculties.

\section{Conclusions}

When we looked in the findings of the study, we found that the classroom teachers' communication skills did not change significantly according to gender. In Durukan and Maden's (2010) study aiming to evaluate the Turkish teachers' communication skills in terms of gender, service length, and graduation, significant differences were found between the teachers' communication skills in favor of the female teachers according to the variable of gender, in favor of the teachers with a professional service length of 1-5 years according to the variable of professional service length and in favor of the teachers having graduated from the Turkish education program according to the undergraduate program from which they had graduated. [21]

Moreover, in their study, Erdem and Okul (2015) examined the differences between the opinions of the classroom teachers working at primary schools in relation to their sills of communication with students and if their opinions changed according to such variables as gender, service length, educational status, the grade which they were teaching and the length of service at the school where they were teaching. It was determined that the classroom teachers' opinions about their skills of communication with students according to the variable of gender differed significantly. The female teachers are of the opinion that they have better skills of communication with students than their counterparts. It was observed that the classroom teachers' opinions about their skills of communication with students did not differ significantly according to the variables of professional service, educational status, the grade which they were teaching and the length of service at the school where they were teaching. [22]

In another study investigating the preservice teachers' perceptions about their skills of communication with students in terms of gender, undergraduate program, class level, settlement unit where they had lived for a long time, high school from which they had graduated, how much and how often they used social networking sites, Ocak and Erşen (2015) aimed to determine the preservice teachers' perceptions about their skills of communication with students. From the scores obtained from the evaluations of the teachers' communication skills, it was concluded that there were significant differences according to gender, undergraduate program, class level and settlement unit which they had lived for a long time but there were no significant differences according to the high school from which they had graduated, how much and how often they used social networking sites. In the study, it was found that the preservice teachers' perceptions about their communication skills were at high level. [23]

The research findings indicated that the classroom teachers' communication skills did not differ significantly according to their service lengths. It was determined that the communication scores of the classroom teachers having graduated from Education Faculties differed significantly from those of the teachers having graduated from other faculties and the communication scores of the teachers having graduated by completing $2+2$ undergraduate degree differed significantly from those of the teachers having graduated from other faculties. In the study made by Şeker [24], it was concluded that the communication skills of the teachers having graduated from Teacher Training School were higher than those of 
the teachers having graduated from other schools. This result shows parallelism with this study. Likewise, in the study made by Ceylan [25], it was found that the teachers having graduated from other faculties had lower level of communication skills. This result is in line with our study. This makes us consider that the teachers graduating from education faculties use field knowledge more effectively compared to those graduating from other faculties.

\section{Suggestions}

Starting from the study findings, the following suggestions can be made:

Training seminars can be prepared in order to improve communication skills of teachers graduating from other faculties.

Reasons why teachers graduating from Education Faculties and Education Institutes are very good at communication skills can be investigated.

In in-service-training seminars, our teachers can be given "Communication Skills Trainings" in order to increase their communication skills.

Since this study is limited to the measurement of communication skills of only classroom teachers, studies can be made more comprehensively or in different branches.

Communication skills of branch teachers can be investigated by taking the variable of branch into consideration.

\section{REFERENCES}

[1] Uğurlu, C. T. (2013). Öğretmenlerin İletişim Becerisi ve Empatik Eğilim Davranışlarının Çocuk Sevme Düzeyleri Üzerine Etkisi, Pegem Eğitim ve Öğretim Dergisi, 3(2), 2013,51-61.

[2] Nacar, F. S. (2010). Sınıf Öğretmenlerinin İletişim ve Kişilerarası Problem Çözme Becerilerinin İncelenmesi, Çukurova Üniversitesi, Sosyal Bilimler Enstitüsü, Yayınlanmamış Yüksek Lisans Tezi, Adana.

[3] Karasakaloğlu, N., Saracaloğlu, A. S., Dedebali N. C. (2010). Yazılı Anlatım Dersinin Sinıf Öğretmeni Adaylarının İletişim Becerileri ile Okuma İlgi ve Alışkanlıklarına Etkisi, Kastamonu Eğitim Dergisi, 18 (2), 389-402.

[4] Dökmen, Ü. (1996). Sanatta ve Günlük Yaşamda İletişim Çatışmaları ve Empati. Sistem Yayıncılık, Ankara.

[5] Topses, G. (2013). Savunucu Kişilik Ölçeğinin Geçerlik Güvenirlik Çalışması, the Journal of Academic Social Science Studies, 6 (1), 1459-1472.

[6] Bangir, G., Senemoğlu, N. (1999). Sınıf İçi İletişimi Kolaylaştırıcı ve Engelleyici Öğretmen-

[7] Birol, C. (1996). Öğretim Elemanlarının İletişimsel Etkililiklerine Yönelik Karşılaştırmalı Değerlendirme,
Yayınlanmamış Yüksek Lisans Tezi, Ankara Üniversitesi Sosyal Bilimler Enstitüsü, Ankara, Türkiye.

[8] Deryakulu, D. (1992). Öğretim Elemanı-Öğrenci Arasındaki İletișimde İstenilen Öğretim Eleman Davranışlarının Gösterilmesini Engelleyen Faktörler, Eğitim Programları ve Öğretim Anabilim Dal Yayınlanmamış Yüksek Lisans Tezi, Ankara Üniversitesi Sosyal Bilimler Enstitüsü, Ankara, Türkiye.

[9] Çetinkanat, C. (1998). Öğretmen Adayları ve Müfettişlerin Bakış Açısından Öğretmen İletişim Becerileri, Eğitim Yönetimi. 4:14: 209-221.

[10] Çam, S. (1997). İletişim Becerileri Eğitim programının Öğretmen Adaylarının Ego Durumuna ve Problem Çözme Becerisi Algılarına Etkisi. Ankara Üniversitesi, Sosyal Bilimler Enstitüsü, Yayınlanmamış Doktora Tezi, Ankara.

[11] Kaya, A. (2010). İletişime Giriş Temel Kavramlar ve Süreçler. Kişilerarası İlişkiler ve Etkili İletişimA. Kaya (Ed.), (Ankara: Pegem Yayınları.

[12] Çetinkanat, A.C. (1997). “Öğretmenlerin İletişim Becerileri”, 3. Ulusal Sınıf Öğretmenliği Sempozyumu, 23-24 Ekim, ss. 17-26, Çukurova Üniversitesi, Adana.

[13] Pehlivan, K. B. (2005). “Öğretmen Adaylarının İletişim Becerisi Algıları Üzerine Bir Çalışma” İlköğretim-online 4 (2) 17-23. (http://ilkogretim-online.org.tr erişim tarihi: 11/04/2014).

[14] Güven, A., Akyüz, M. Y. (2001). Öğretmen Adaylarının İletişim ve Problem Çözme Becerilerine İlişkin Görüşleri, Ege Eğitim Dergisi, (1)1, 13-22.

[15] Ergün, M., Özdaş, A. (1999). Okul Gözlemi ve Uygulama Çalışmalarının Öğretmen Adayları Üzerindeki Etkisi. AKÜ Sosyal Bilimler Dergisi, 3, 115-119.

[16] Bulut, N. (2003). İlköğretim Sınıf Öğretmenlerinin İletişim Becerilerine İlişkin Algılarının Çeşitli Değişkenler Açısından İncelenmesi, XII. Eğitim Bilimleri Kongresi, Gazi Üniversitesi: Antalya.

[17] Jones, V. F., Jones, L. S. (1998). Comperehensive classroom management. Massachusetts: Allyn and Bacon.

[18] Öztürk, B. (2009). Sınıfta Istenmeyen Davranışların Önlenmesi Ve Giderilmesi. E. Karip (Ed.). Sınıf yönetimi. Ankara: Pegem Akademi Yayıncılık.

[19] Geng, G. (2011). Investigation Of Teacherse Verbal And Non-Verbal Strategies For Managing Attention Deficit Hyperactivity Disorder (Adhd) Studentse Behaviours Within A Classroom Environment. Australian Journal of Teacher Education. Charles Darwin University, 36(7), 17-30.

[20] Çubukçu, Z., Girmen, P. (2008). Öğretmenlerin Sinıf Yönetimi Becerilerine Ilişkin Görüşleri. Türk Dünyası Sosyal Bilimler Dergisi. 44, 123-142.

[21] Durukan, E., Maen, S. (2010). Türkçe Öğretmenlerinin Iletişim Becerileri Üzerine Bir Inceleme. Sosyal Bilimler Araştırmaları Dergisi, 1, 59-74.

[22] Erdem, A. R., Okul, Ö. (2015). Sınıf Öğretmenlerinin Öğrencilerle Iletişim Becerileri. Çağdaş Yönetim Bilimleri Dergisi, 1(1). 
[23] Ocak, G., Erşen, Z. B. (2015). Öğretmen Adaylarının Iletişim Becerileri Algılarının Incelenmesi. Mehmet Akif Ersoy Üniversitesi Eğitim Fakültesi Dergisi, 1(33), 1-19.

[24] Şeker, A. (2000). "Sınıf Öğretmenlerinin İletişim Becerileri İle Sınıf Atmosferi Arasındaki İlişkinin Çeşitli Değişkenler
Açısından İncelenmesi”, Yayımlanmamıs Yüksek Lisans Tezi, Selçuk Üniversitesi Sosyal Bilimler Enstitüsü, Konya.

[25] Ceylan, G. (2007). "Öğretmen-Öğrenci Etkileşimin Sınıf Atmosferine Etkisi”, Yayınlanmamış Yüksek Lisans Tezi, Selçuk Üniversitesi Sosyal Bilimler Enstitüsü, Konya. 